\title{
Contrasting Impacts of Cultivated Exotics on the Functional Diversity of Domestic Gardens in Three Regions with Different Aridity
}

\author{
Josep Padullés Cubino, ${ }^{1,2 *} \odot$ Dorothy Borowy, ${ }^{3} \odot$ Sonja Knapp, ${ }^{4,5} \odot$ \\ Zdeňka Lososová, ${ }^{2} \odot$ Carlo Ricotta, ${ }^{6} \odot$ Stefan Siebert, ${ }^{\circledR} \odot$ Jeannine Cavender- \\ Bares, ${ }^{1} \odot$ Daniel Sol, ${ }^{8} \odot$ Alienor Jeliazkov, ${ }^{9,10} \odot$ and Christopher Swan ${ }^{3} \odot$
}

\begin{abstract}
${ }^{1}$ Department of Ecology, Evolution and Behavior, University of Minnesota, 1479 Gortner Ave, St. Paul, Minnesota 55108, USA; ${ }^{2}$ Department of Botany and Zoology, Masaryk University, Kotlářská 2, 61137 Brno, Czech Republic; ${ }^{3}$ Department of Geography and Environmental Systems, University of Maryland, Baltimore County, 1000 Hilltop Circle, Baltimore, Maryland 21250, USA; ${ }^{4}$ Helmholtz-Centre for Environmental Research - UFZ, Department of Community Ecology, Theodor-Lieser-Str. 4, 06120 Halle (Saale), Germany; ${ }^{5}$ Department of Ecology, Chair of Urban Ecosystem Science, Technische Universität Berlin, Rothenburgstr. 12, 12165 Berlin, Germany; ${ }^{6}$ Department of Environmental Biology, University of Rome, 'La Sapienza', Piazzale Aldo Moro 5, 00185 Rome, Italy; ${ }^{7}$ Unit for Environmental Sciences and Management, North-West University, Potchefstroom 2520, South Africa; ${ }^{8}$ CREAF-CSIC (Centre for Ecological Research and Applied Forestries), 08193 Cerdanyola Del Vallès, Catalonia, Spain; ${ }^{9}$ German Centre for Integrative Biodiversity Research (iDiv), Halle-Jena-Leipzig, 04103 Leipzig, Germany; ${ }^{10}$ Institute of Computer Science, Martin Luther University HalleWittenberg, 06120 Halle (Saale), Germany
\end{abstract}

\begin{abstract}
Cultivated exotic plants are often introduced for their aesthetic value and today comprise a substantial fraction of the flora of urban domestic gardens. Yet, their relative contribution to the functional diversity of domestic gardens and how it changes across different climate zones is insufficiently understood. Here, we investigated whether the effects of cultivated exotics on functional diversity of three plant traits related to plant aesthetics (that is, plant showiness, plant height, and leaf area) varied in suburban domestic gardens in three regions
\end{abstract}

Received 4 March 2020; accepted 28 August 2020; published online 19 September 2020

Electronic supplementary material: The online version of this article (https://doi.org/10.1007/s10021-020-00556-x) contains supplementary material, which is available to authorized users.

Author Contributions: All authors participated to the conception of the study. JPC analyzed data. All authors contributed to the writing and approved the final version of the manuscript.

*Corresponding author; e-mail: padullesj@gmail.com
(Minnesota, USA; Alt Empordà, Spain; and central South Africa) that differ in aridity. For each garden, we calculated the mean and variance of each plant trait considering all co-occurring species and also splitting them into co-occurring cultivated exotics and natives. Our results revealed that mean plant showiness increased linearly with the proportion of cultivated exotics both across and within studied regions. Moreover, co-occurring cultivated exotics were, on average, showier than natives in all regions, but differences in their trait variances were context-dependent. The interaction between cultivated exotics and aridity explained variation in mean plant height and leaf area better than either predictor alone, with the effect of cultivated exotics being stronger in more arid regions. Accordingly, cooccurring cultivated exotics were taller and had larger leaves than natives in warmer and drier regions, while the opposite was true in cooler and wetter regions. Our study highlights the need to consider the combined effects of exotic species and climate in future studies of urban ecology. 
Key words: Climate change; Horticulture; Human preferences; Introduced species; Plant traits; Urban ecosystems; Urbanization.

\section{Highlights}

- The interaction between exotics and aridity drove functional diversity in gardens.

- The effect of this interaction was positive and stronger in more arid regions.

- Exotics were on average showier than co-occurring natives in all regions.

\section{INTRODUCTION}

As the world becomes more urbanized (UN DESA 2018), urban plant communities are becoming increasingly important for maintaining biodiversity (Aronson and others 2014, 2016) and providing ecosystem services (Tratalos and others 2007). Although exotic plants comprise a substantial fraction of the urban flora (Pyšek and others 2010) and are often assumed to increase taxonomic diversity in urban environments (Pearse and others 2018), their contributions to ecosystem function and the delivery of ecosystem services to urban residents across different environmental and social contexts are insufficiently understood (Cook-Patton and Agrawal 2014).

Urban plant species, both native and exotic, can be broadly classified into two groups: cultivated (that is, plants that are intentionally introduced and managed by humans) and spontaneous (that is, plants that colonize and establish without human assistance). The relative abundance of species representing each group varies across urban habitat types with different levels of human management (for example, parks, gardens, abandoned land) (Aronson and others 2016). Among urban habitat types, domestic gardens represent highly managed areas where gardening practices in the form of soil amendments, supplemental watering, weeding, and fertilization have been shown to partly override climatic stress and other natural environmental filters (Kendal and others 2012b; Groffman and others 2016; Padullés Cubino and others 2019), and favor the persistence of a large number of cultivated species with different functional strategies (Marco and others 2010; Bigirimana and others 2012; van Heezik and others 2013).
Cultivated species in gardens are largely selected from the horticultural pool (Cavender-Bares and others 2020) based on homeowners' preferences for certain traits associated with these species, including low water requirements, a specific size at maturity, and showy flower displays (for example, Kendal and others 2012a; Goodness 2018; Pearse and others 2018). These traits have often been referred to as 'ecosystem-service based traits' (Pataki and others 2013), as opposed to the suite of traits commonly used in ecological studies (Cornelissen and others 2003; Pérez-Harguindeguy and others 2013). In this regard, the aesthetic value associated with more colorful vegetation has been considered an important cultural ecosystem service that contributes to human well-being in urban areas (Ulrich 1986; Millennium Ecosystem Assessment 2005) although it can be perceived differently by different social and cultural groups (Marco and others 2010). Although the scientific literature indicates that ecosystem-service based traits associated with visual aesthetics tend to be of high priority for the configuration of the floras in domestic gardens (reviewed in Goodness and others 2016), we have a relatively poor understanding of the contribution of cultivated exotics to the diversity of these traits, and whether trait diversity of cultivated exotics and natives differs across climatic zones.

Climate has been shown to be the major driver of garden plant diversity and composition at large spatial scales (Loram and others 2008; Pearse and others 2018; Padullés Cubino and others 2019). Low and highly variable precipitation (that is, increased aridity) induces water stress in native plants affecting their growth, photosynthetic ability, and ultimately their distribution. Unlike other climatic constraints, such as extreme temperatures, water availability in gardens can be regulated by irrigation, allowing cultivated exotic plants to persist in areas where natural conditions would otherwise be unsuitable. As a result, trait differences between co-occurring native and cultivated exotic plants in gardens are expected to increase with aridity, leading to contrasting patterns of plant functional diversity in regions with varying aridity. To date, few studies have considered how exotic species and water availability collectively influence diversity patterns (for example, Nobis and others 2009), despite a number of scientific studies urging for a more integrated approach (Walther and others 2009).

The connection between functional traits and ecosystem services is well documented for a wide 
range of ecosystems (reviewed in de Bello and others 2010). However, this connection has not been fully described in novel urban ecosystems, particularly for cultural ecosystem services (for example, Goodness and others 2016; Avolio and others 2018). In addition, no single functional diversity measure captures all of the relevant information needed for drawing mechanistic links between functional traits and ecosystem function (for example, Pavoine and others 2017). As a result, complementary measures, which cover specific aspects of community functional structure, are required (Figure 1). First, community mean (CM) trait values describe how a group of co-occurring species collectively contribute to a specific ecosystem function, which can, in turn, translate into a range of ecosystem services. For example, if cultivated exotics show larger CM values for plant height than natives in a domestic garden, then this likely indicates that cultivated exotics contribute more to certain ecosystem services (for example, provision of shade) or disservices (for example, dropping of debris) than co-occurring natives (Avolio and others 2018). Second, community trait variability (or trait variance; $\mathrm{CV}$ ) defines the total community trait space occupied by a group of cooccurring species. Again, if cultivated exotics have a greater $\mathrm{CV}$ for plant height than natives in a domestic garden, then this suggests they have a wider range of altitudes (that is, occupy a wider, and likely novel, trait space), which could translate into greater provisioning of ecosystem services, and disservices. This approach can also be extended from groups of co-occurring species to groups of communities in a particular landscape.

Here, we apply this framework to investigate the role of cultivated exotic plants in determining functional diversity of traits related to visual attraction and aesthetic appeal in domestic gardens in suburban areas of three regions that vary in aridity (Minnesota, USA; Alt Empordà, Spain; and central South Africa). To this end, we selected three plant traits representing visual aesthetic characteristics: plant showiness, plant height, and leaf area. These traits have been linked to residents' preferences in a number of urban studies (Acar and others 2007; Goodness and others 2016; Padullés Cubino and others 2020). Showy plants with colorful flowers, fruits, and leaves have often been documented as more desirable in urban landscaping, due to their inherent aesthetic value (Kaufman and Lohr 2004; Todorova and others 2004; Kendal and others 2012a). Studies have also suggested that distinct levels of plant heights (that is, greater vegetation structural complexity) increase aesthetic appeal (Ulrich 1986; Kaplan and Kaplan 1989; Southon and others 2017), as well as certain leaf morphologies and complex broad-leaved foliage
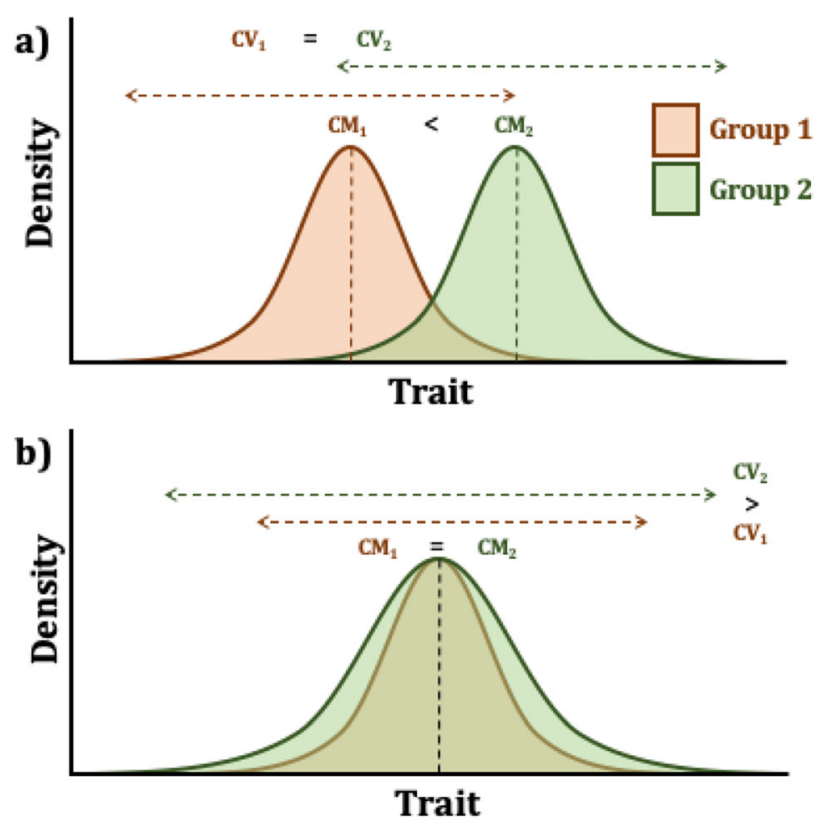

Figure 1. Diagram exemplifying differences between two trait measures (that is, community mean (CM) and variance $(\mathrm{CV}))$ in different groups of species. In case a), the two groups have different mean trait values $\left(\mathrm{CM}_{2}>\mathrm{CM}_{1}\right)$, but equal trait variances. In case b), the two groups have equal mean trait values, but different trait variances $\left(C_{2}>C V_{1}\right)$. This same approach could be applied to a group of communities instead of species. 
(Williams 2002; Lindemann-Matthies and Bose 2007). Understanding how human-mediated selection for these traits induces differences in the functional diversity of exotic and native species is crucial for the design and planning of sustainable landscapes that aim to maximize the provision of ecosystem services.

Our analyses are based on plant presence/absence data for 460 domestic gardens in suburban areas located on three different continents (North America, Europe, and Africa). Suburban areas in these three regions (Minnesota, Alt Empordà, and central South Africa) share a common European gardening culture centered around aesthetic ecosystem services but differ in a number of characteristics such as their cultural and socio-economic background, biogeographic history, or climate (Lubbe and others 2010; Padullés Cubino and others 2015; Cavender-Bares and others 2020). We use the distribution of the three regions along a major global aridity gradient to assess whether the influence of cultivated exotics on the functional diversity in gardens varies as a function of climate.

We specifically address three questions: (1) How does the proportion of cultivated exotic plant species relate to the functional trait diversity of domestic gardens? (2) Do cultivated exotics influence functional trait diversity of gardens differently across a global aridity gradient? (3) Do cultivated exotics differ from co-occurring natives in functional trait diversity in regions with different levels of aridity? Because homeowners often select for cultivated species with different colors and aesthetic characteristics (Goodness and others 2016), we hypothesized that higher proportions of cultivated exotics in domestic gardens would be positively associated with functional diversity of plant showiness. We also expected the interaction between cultivated exotics and aridity to be important in explaining variation in plant height and leaf area, given that irrigation by homeowners can compensate for the lack of precipitation in more arid regions (Kendal and others 2012b; Padullés Cubino and others 2019), creating newly available niches that can potentially be filled by cultivated exotics. Consequently, we expected co-occurring cultivated exotics to be taller and have larger leaves than natives in more arid regions. Nonetheless, we expected co-occurring cultivated exotics to be, both on average and in their distribution, showier than natives regardless of aridity.

\section{Materials AND Methods}

\section{Study Areas and Vegetation Data}

For the purpose of this study, domestic gardens (or only 'gardens') were defined as the private land around a detached, semi-attached, or attached single-family home that is actively managed primarily for aesthetic purposes. We extracted information on vascular plant species occurrence in 460 gardens from various datasets encompassing suburban areas in three regions: Minnesota, USA; Alt Empordà, Spain; and central South Africa. To ensure consistent sampling effort in our data, extracted data in each region matched four conditions: (1) Gardens were actively managed by live-in owners or tenants (that is, non-abandoned), (2) plant data were recorded at the individual garden level, (3) garden area was recorded, and (4) data contained an exhaustive list of all plant species (that is, both cultivated and spontaneously occurring plants) present in the garden. Data from Minnesota, USA, included 155 domestic gardens sampled in the Minneapolis-St. Paul metropolitan area between 2008 and 2012. The Alt Empordà region in northeastern Spain included 258 domestic gardens distributed among five neighboring municipalities that were sampled in 2012. Finally, data from central South Africa included 150 domestic gardens distributed between two municipalities located approximately $100 \mathrm{~km}$ apart (Johannesburg and Tlokwe) that were sampled between 2008 and 2011 . We considered gardens in this region to be in the same geographic unit because species composition was consistently homogeneous across the region (Appendix S1: Figure S2). To standardize sampling efforts among cities, we randomly subsampled 155 gardens in Alt Empordà to make the data comparable to Minnesota and South Africa. Details on site selection and data collection in each location can be found in the references provided in Table 1, and in Appendix S1: Table S1.

In all datasets, plants were identified to the species level by trained botanists and the support of specialized literature. For those species that could not be identified at the species level, the genus was recorded $(\sim 9 \%)$. We retained records for hybrid species $(\sim 8 \%)$, but excluded hybrid genera $(<1 \%)$. Species were designated as either spontaneous or cultivated based on homeowner interviews, observations of placement, land use, and land-use history. We standardized nomenclature for all species according to accepted name in the Plant List (www.theplantlist.org) version 2.1 using 
Table 1. Location, Number of Gardens, Climate, and References for Each Dataset.

\begin{tabular}{|c|c|c|c|c|c|c|}
\hline $\begin{array}{l}\text { Region } \\
\text { (country) }\end{array}$ & $\begin{array}{l}\text { Latitude; } \\
\text { Longitude }^{\text {a }}\end{array}$ & $\begin{array}{l}\text { Number of } \\
\text { analyzed } \\
\text { gardens }\end{array}$ & $\begin{array}{l}\text { Mean Annual } \\
\text { Temperature } \\
\left({ }^{\circ} \mathrm{C}\right)^{\mathrm{b}}\end{array}$ & $\begin{array}{l}\text { Annual } \\
\text { Precipitation } \\
(\mathrm{mm})^{2}\end{array}$ & $\begin{array}{l}\text { Aridity } \\
\text { index } \\
\left({ }^{*} 10,000\right)^{\mathrm{c}}\end{array}$ & Dataset references $^{4}$ \\
\hline $\begin{array}{l}\text { Minnesota } \\
\text { (USA) }\end{array}$ & $\begin{array}{l}44.97 \\
\quad-93.19\end{array}$ & 155 & 7.0 & 754 & 8291 & $\begin{array}{l}\text { Cavender-Bares and others } \\
\text { (2019), Padullés Cubino and } \\
\text { Narango (2019) }\end{array}$ \\
\hline $\begin{array}{l}\text { Alt Empordà } \\
\text { (Spain) }\end{array}$ & $42.25 ; 3.12$ & 155 & 15.2 & 531 & 6118 & Padullés Cubino (2019) \\
\hline South Africa & $\begin{array}{c}-26.20 \\
28.04\end{array}$ & 150 & 16.7 & 720 & 4271 & Siebert and others (2020) \\
\hline
\end{tabular}

\footnotetext{
${ }^{a}$ The spatial distribution of domestic gardens within regions can be found in Appendix S1: Figure S1.

${ }^{b}$ Climatic data represent average values across all households in each city. Mean annual temperature and annual precipitation were obtained from the WorldClim database $v .2$ (www.worldclim.org/version2). Additional climatic data can be found in Appendix S1: Table S2.

${ }^{c}$ Details on the calculation of the aridity index can be found in the Methods. Aridity index values increase for cooler and wetter conditions and decrease with warmer and drier conditions.

${ }^{4}$ A complete list of publications derived from these datasets can be found in Table S1.
}

the $\mathrm{R}$ package Taxonstand (Cayuela and others 2017). In total, studied gardens contained 1863 taxa.

\section{Native Species Status}

We classified species as native or exotic in each city using database information and peer-reviewed literature. Specifically, we used USDA PLANTS (ww w.plants.usda.gov) and EOL (www.eol.org) databases for classifying garden species in Minnesota. For gardens in Alt Empordà, we classified species as native or exotic according to Bolós and others (2005). Finally, we followed Germishuizen and others (2006) and Glen (2002) for classifying garden species in central South Africa. Hybrid species were classified as exotic. The proportion (\%) of cultivated exotic species in gardens ranged from $3 \%$ to $74 \%$ in Minnesota, from 12 to $92 \%$ in Alt Empordà, and from $0 \%$ to $72 \%$ in central South Africa (Appendix S1: Figure S3).

\section{Plant Traits Related to Visual Aesthetics}

We assigned trait values to all recorded species. Plant showiness was calculated for all species as the sum of three independent categorical plant traits: flower, fruit, and foliage showiness (Avolio and others 2015; Padullés Cubino and others 2020). Flower showiness was divided into three categories: 0 for species that did not flower or had inconspicuous flowers; 1 for species whose flowers are visible and conspicuous; and 2 for species with large showy flowers. Fruit showiness consisted of two categories: non-visible (0) or visible (1) fruits or berries. Foliage showiness also consisted of two categories that depended on whether leaves turn color in the fall or have whitish, bluish, or other neutral tones in their leaves (for example, Silene coronaria, Codiaeum variegatum) (1), in contrast to leaves that are only green (0). Data for these traits were obtained from the USDA PLANTS database, the Missouri Botanical (www.missouribotanicalga rden.org), and specialized floras such as Bolós and others (2005) and Glen (2002).

Plant height and leaf area were collected from the TRY database (www.try-db.org; additional references are provided in Appendix S2). We excluded trait records for plant height and leaf area with a distance greater than 4 standard deviations from the mean of species or genus to avoid any potential effect of outliers (Díaz and others 2016). We then calculated species' mean trait values with the retained plant trait records. All traits were available for at least $57 \%$ of the species in each region (Appendix S3: Table S3).

\section{Missing Trait Data Imputation}

To account for missing data, we imputed trait values using phylogenetic information from closely related species with available data (Swenson 2014). We relied on data imputation versus selective removal of species with unavailable trait information because it avoids potential bias resulting from the removal of rare species sampled in different regions. First, we constructed a phylogenetic tree using an updated version of the Zanne and others (2014) phylogeny constructed by Qian and Jin 
(2016). We added species missing from this phylogeny at the genus level using the 'congeneric.merge' function in the $\mathrm{R}$ package pez (Pearse and others 2015). Hybrid species and those recorded at the genus level were also added to the phylogeny when possible. We excluded about $2.7 \%$ of the taxa from the analysis for which there were no phylogenetic data. Second, we used the R package Rphylopars (Goolsby and others 2017) to compare available trait data across four alternative evolutionary models (that is, Early Burst, Brownian motion, Ornstein-Uhlenbeck, and multivariate Ornstein-Uhlenbeck). We selected the best-fitting model based on the lowest AIC value (that is, Ornstein-Uhlenbeck) to impute trait data. Further details on missing trait data imputation and performance assessment can be found in Appendix S3.

After completing trait data imputation, we established a maximum plant height of 25 meters and assigned this value to all species taller than 25 $\mathrm{m}$. We did this based on the authors' personal observations and knowledge that human management rarely allows tall trees to achieve their maximum height in domestic gardens. We also tested the limitations of assigning a maximum plant height value by repeating analyses using different maximum plant heights to assess their effect on the results, but they all showed similar patterns (Appendix S4).

\section{Aridity Index}

The three regions included in our study are located along a global aridity gradient (from cooler and wetter to warmer and drier: Minnesota, Alt Empordà, and central South Africa, respectively) that maximizes climatic differences among these areas better than other variables such as mean annual temperature, annual precipitation, or the maximum and minimum temperatures of the warmest and coldest month (Table 1; Appendix S1: Table S2).

To quantify the aridity gradient and account for its influence in our models, we downloaded the global aridity index (hereafter aridity index) data from the Consortium for Spatial Information's (CGIAR-CSI) website (www.cgiarcsi.community) (Trabucco and Zomer 2019). The mean aridity index from the 1950-2000 period was available at 30 arc second spatial resolution and is calculated as:

$$
\text { Aridity index }=\mathrm{MAP} / \mathrm{MAE}
$$

where MAP is the mean annual precipitation, and MAE the mean annual potential evapotranspiration. MAP values were obtained from the World-
Clim database v.2 (www.worldclim.org/version2) (Fick and Hijmans 2017), whereas MAE values were aggregated from potential evapotranspiration layers estimated on a monthly average based on the Penman-Monteith equation (see Trabucco and Zomer 2019). Aridity index values increase for cooler and wetter conditions and decrease with warmer and drier conditions. We extracted the mean aridity index for each plot in our study using the $\mathrm{R}$ package raster (Hijmans 2019).

\section{Statistical Analysis}

We established significance at $\alpha<0.05$ and performed all statistical analyses in $\mathrm{R}$ version 3.5.3 ( $\mathrm{R}$ Core Team. 2019). We calculated the community mean (CM) and variance (CV) of plant showiness, plant height, and leaf area in each garden considering (1) all co-occurring species, and (2) separately for co-occurring cultivated exotics and natives (that is, including both cultivated and spontaneously occurring natives). We chose trait variance over trait range as a measure of trait dispersion because it is less sensitive to the effect of outliers.

We modeled CM and CV of each trait considering all co-occurring species across all gardens as a function of the proportion (\%) of cultivated exotics and the aridity index (fixed effects, previously standardized and centered; Zuur and others (2007)), using linear mixed-effects models with the 'lme' function in $\mathrm{R}$ package nlme (Pinheiro and others 2018). Leaf area was log-transformed prior to analysis to reduce skewness and improve the normality of the residuals. In all models, we included 'region' (that is, Minnesota, Alt Empordà, South Africa) as a random effect to account for large-scale spatial patterns and other region-specific characteristics. In addition, because gardens in South Africa were split into two relatively distant cities (that is, Johannesburg and Tlokwe; Figure S1), we also nested 'city' within 'region' in the random effect. Overall, we investigated five candidate models resulting from the combination of both predictors and their interaction: aridity index (M1), \% of cultivated exotics (M2), log-transformed \% of cultivated exotics (M3; to account for potential nonlinear and saturating effects), the combined effects of aridity index and \% of cultivated exotics (that is, aridity index $+\%$ cultivated exotics; M4), and the interaction between aridity index and \% of cultivated exotics (that is, aridity index * \% cultivated exotics; M5). To account for potential species-area effects, we included the logtransformed area of each garden as a covariate in all models. We also included a null model with only 
the log-transformed garden area as a fixed effect and location as a random factor (M0). We calculated the $\mathrm{AIC}_{\mathrm{c}}$ (the small-sample-size-corrected Akaike information criterion; Anderson 2008) values of each candidate model set and ranked the models by their Akaike weights using the $\mathrm{R}$ package AICcmodavg (Mazerolle 2019). We used the function 'modavgPred' in the same package to compute the model-averaged predictions, which is the natural average and reduces concerns about bias away from zero (Cade 2015). To assess the predictive power of the models, we calculated marginal and conditional $\mathrm{R}$-squared from the $\mathrm{R}$ package MuMIn (Bartón 2019). To assess whether response variables and derived model residuals were spatially autocorrelated, we calculated Moran's I with $\mathrm{R}$ package ape (Paradis and Schliep 2019).

We used independent Mann-Whitney U test for nonparametric samples to test for significant differences in mean garden trait values between cooccurring cultivated exotics and all natives in each location. Similarly, we used F-tests to test for differences in the distribution of mean garden trait values between the two groups of species. We use the term 'distribution' here instead of 'variance' to avoid confusion between variance across gardens (distribution) and variance across species (CV). We plotted density curves to visualize differences between the two groups. We adopted a conservative approach and compared cultivated exotics versus all natives (rather than only cultivated natives) because a number of homeowners reported that many desired natives grew spontaneously in their gardens, and the distinction between 'spontaneous' and 'cultivated' natives was not always clear.

\section{RESUlts}

The model including the interaction between the proportion of cultivated exotics and the aridity index was selected among the best models $\left(\Delta \mathrm{AIC}_{\mathrm{c}}<2\right)$ for all response variables, except for $\mathrm{CV}$ of leaf area (Table 2). The coefficients of these interactions were negative in all cases (Table 2; Appendix S5: Figure S5), indicating that the contribution of the proportion of cultivated exotics in increasing response variables was higher in more arid regions. The model including the logarithmic proportion of cultivated exotics best-explained variation in CV of leaf area. Moran's I for model residuals indicated our predictor variables significantly reduced the effect of spatial autocorrelation (Appendix S5: Table S6).
Within locations, the proportion of cultivated exotics was consistently and positively associated with CM of plant showiness (Figure 2A). However, $\mathrm{CV}$ of plant showiness was only positively associated with the proportion of cultivated exotics in South Africa (Figure 2B). For plant height, both $\mathrm{CM}$ and $\mathrm{CV}$ were positively associated with the proportion of cultivated exotics in South Africa but negatively associated with the proportion of cultivated exotics in Minnesota (Figure 2C-D). The association between $\mathrm{CM}$ of plant height and the proportion of cultivated exotics was also positive in Alt Empordà, albeit weaker than in South Africa (Figure 2C). We found no significant association between $\mathrm{CV}$ of plant height and the proportion of cultivated exotics in Alt Empordà (Figure 2D). For leaf area, we found positive associations between both CM and CV and the proportion of cultivated exotics in all locations (Figure 2E-F), except for CV in Alt Empordà, where the association was not significant. Nonetheless, regression coefficients for CM of leaf area decreased from more to less arid conditions. We found consistent effects of the proportion of cultivated exotics on functional diversity of the two South African cities (Johannesburg and Tlokwe), thus supporting the inclusion of the two cities under the same region in our analyses (Appendix S5: Figure S6).

Co-occurring cultivated exotics were, on average, showier than co-occurring natives (hereafter only 'cultivated exotics' and 'natives'), regardless of their location (Figure 3A, D, G; Appendix S5: Table S7). However, the variance in the distribution of plant showiness was greater among natives than among cultivated exotics only in Alt Empordà, and we found no significant differences in Minnesota or South Africa. Cultivated exotics were, on average, shorter and had a narrower distribution of plant height than natives in Minnesota (Figure 3B; Table S7), whereas the exact opposite pattern (that is, taller cultivated exotics with greater distribution than natives) was observed in South Africa (Figure 3H; Table S7). Alt Empordà showed a transient state between the two. In this case, cultivated exotics were taller on average than natives and their distribution did not differ (Figure 3E; Table S7). Leaf area among cultivated exotics was, on average, larger and had a greater distribution than natives in Alt Empordà (Figure 3F; Table S7), and South Africa (Figure 3I; Table S7). In Minnesota, the distribution of leaf area was also greater among cultivated exotics than among natives, but mean leaf area was larger among natives (Figure 3C; Table S7). The highest trait distribution overlap between cultivated exotics and natives 


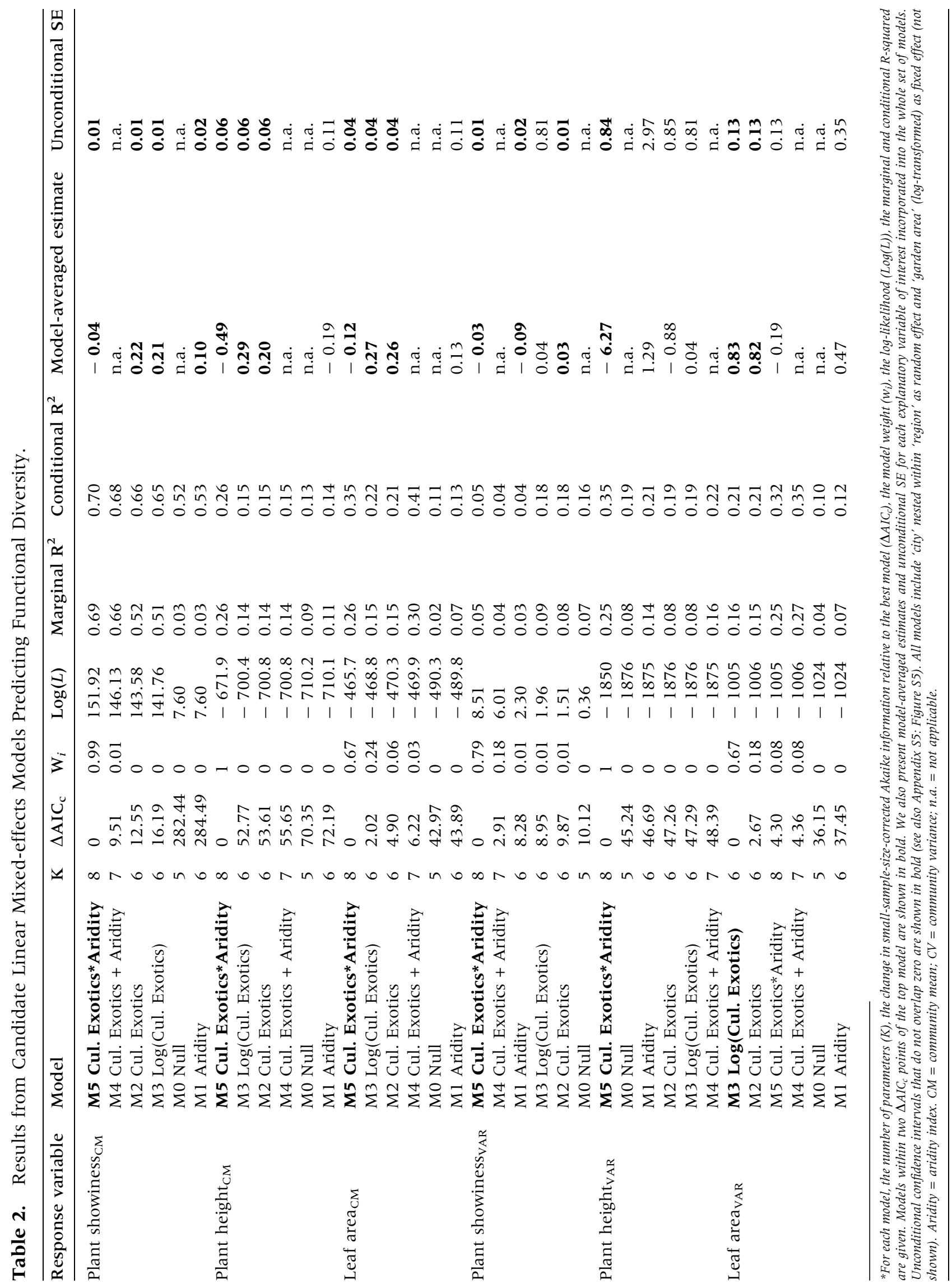



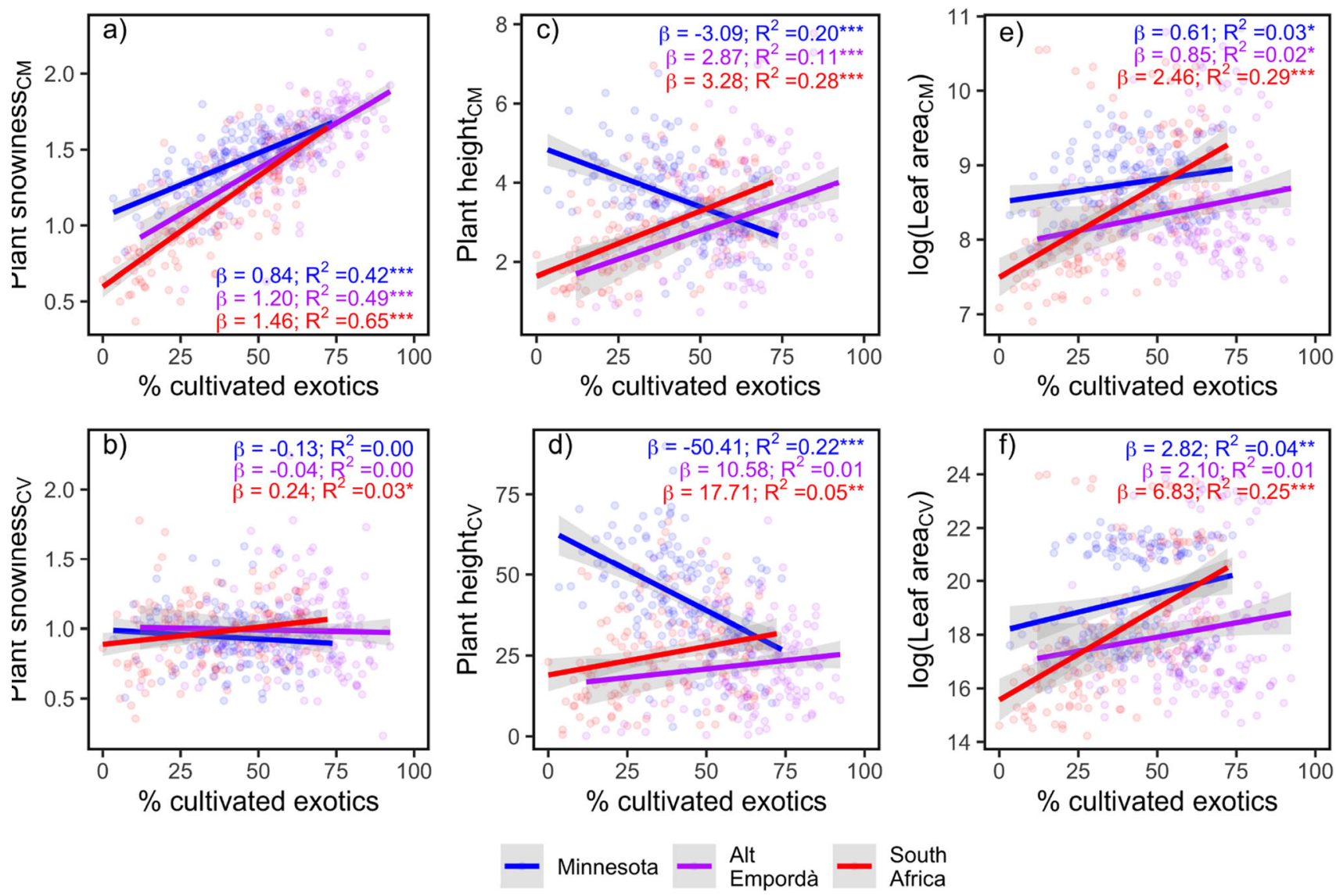

Figure 2. Relationship between the mean (top row) and variance (bottom row) of the three plant traits (that is, plant showiness, plant height, and leaf area) and the proportion (\%) of cultivated exotics in domestic gardens. In each plot, points and linear regressions are colored according to 'region'. Blue colors represent cooler and wetter conditions (that is, Minnesota), red colors represent warmer and drier conditions (that is, central South Africa), and violet colors intermediate conditions between the two (that is, Alt Empordà). Shaded areas indicate $95 \%$ confidence intervals. Standardized regression coefficients $(\beta)$, and adjusted $\mathrm{R}^{2}$ are also provided. * ** and *** indicate significant interactions at $P<0.05,0.01$, and 0.001 , respectively.

across locations was for leaf area, and the lowest for plant showiness (Figure 3).

The proportion of gardens where CM and CV of each trait was higher among cultivated exotics than among natives tended to increase with more arid conditions, except for CM of plant showiness that remained constant (see stacked bar plots in Figure 3).

\section{Discussion}

Using a transcontinental dataset, our study showed that increased proportions of cultivated exotics had contrasting effects on different plant traits related to the visual aesthetics of suburban domestic gardens. Following our initial hypothesis, and across three suburban areas in the USA, Spain, and South Africa, we found that the vegetation in domestic gardens consistently contained showier (more colorful) flowers, fruits, and leaves with increased relative number of cultivated exotics. In addition, co-occurring cultivated exotics were, on average, more colorful than co-occurring natives, and the distribution of plant showiness between the two groups of species showed little overlap $(<25 \%)$.

These findings confirm that ornamental exotics largely contribute to increasing visual attractiveness in private urban landscapes (Bigirimana and others 2012; Avolio and others 2019) and that combinations of native species in gardens are notably less showy than gardens composed of cultivated exotics. Nonetheless, a large number of natives had higher values of plant showiness than cultivated exotics at the regional level for all three locations (Appendix S5: Figure S7), which indicates that there is potential to create combinations of 


\section{Minnesota}
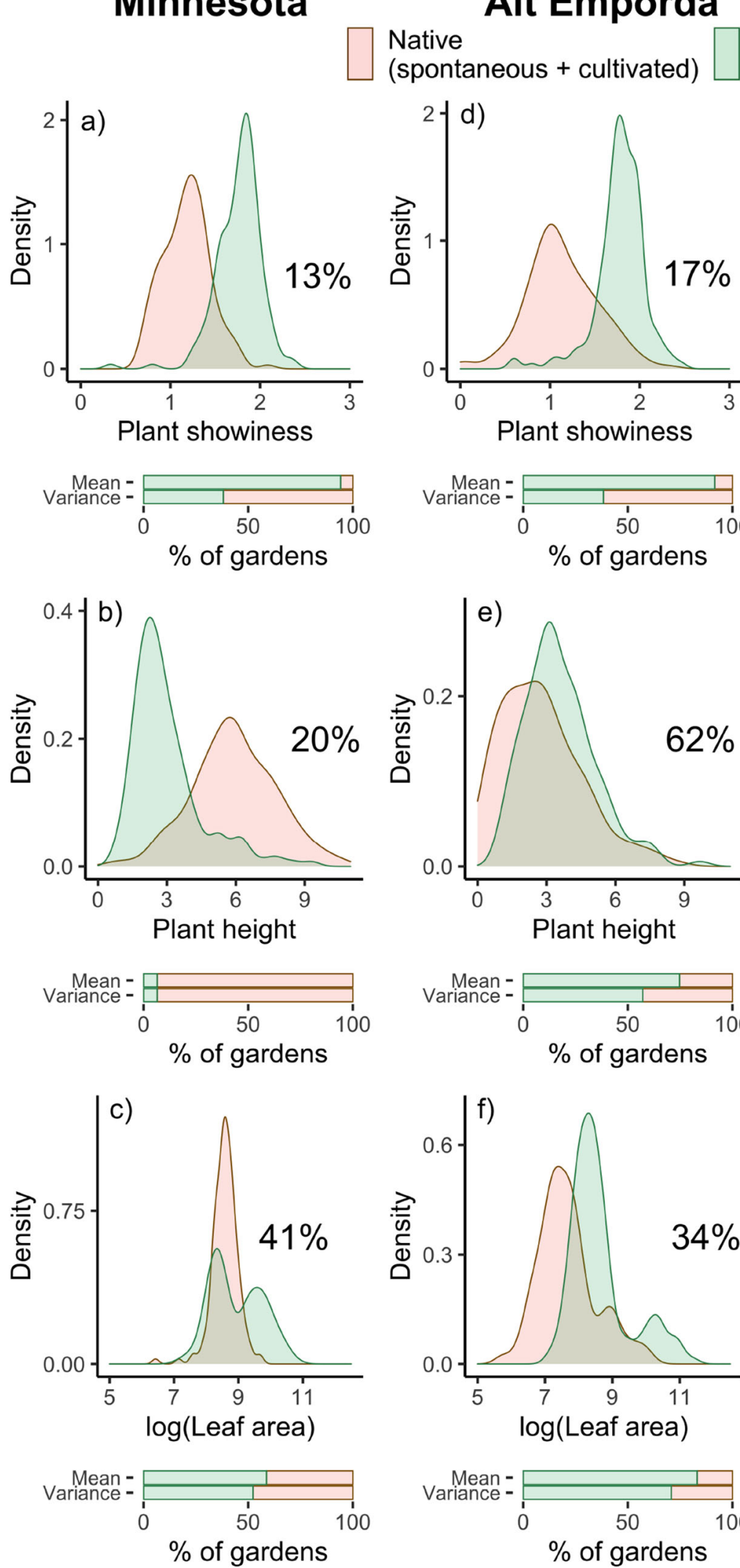

Alt Empordà

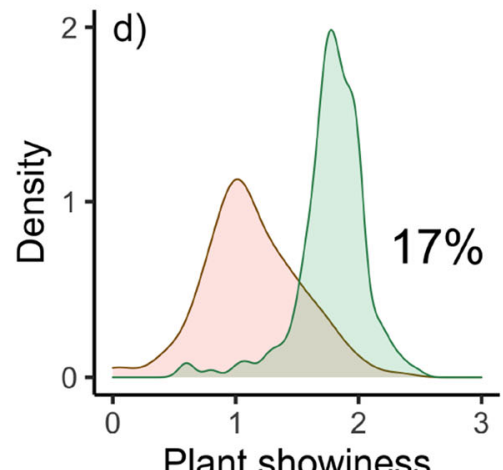

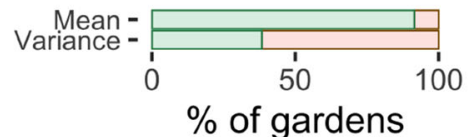
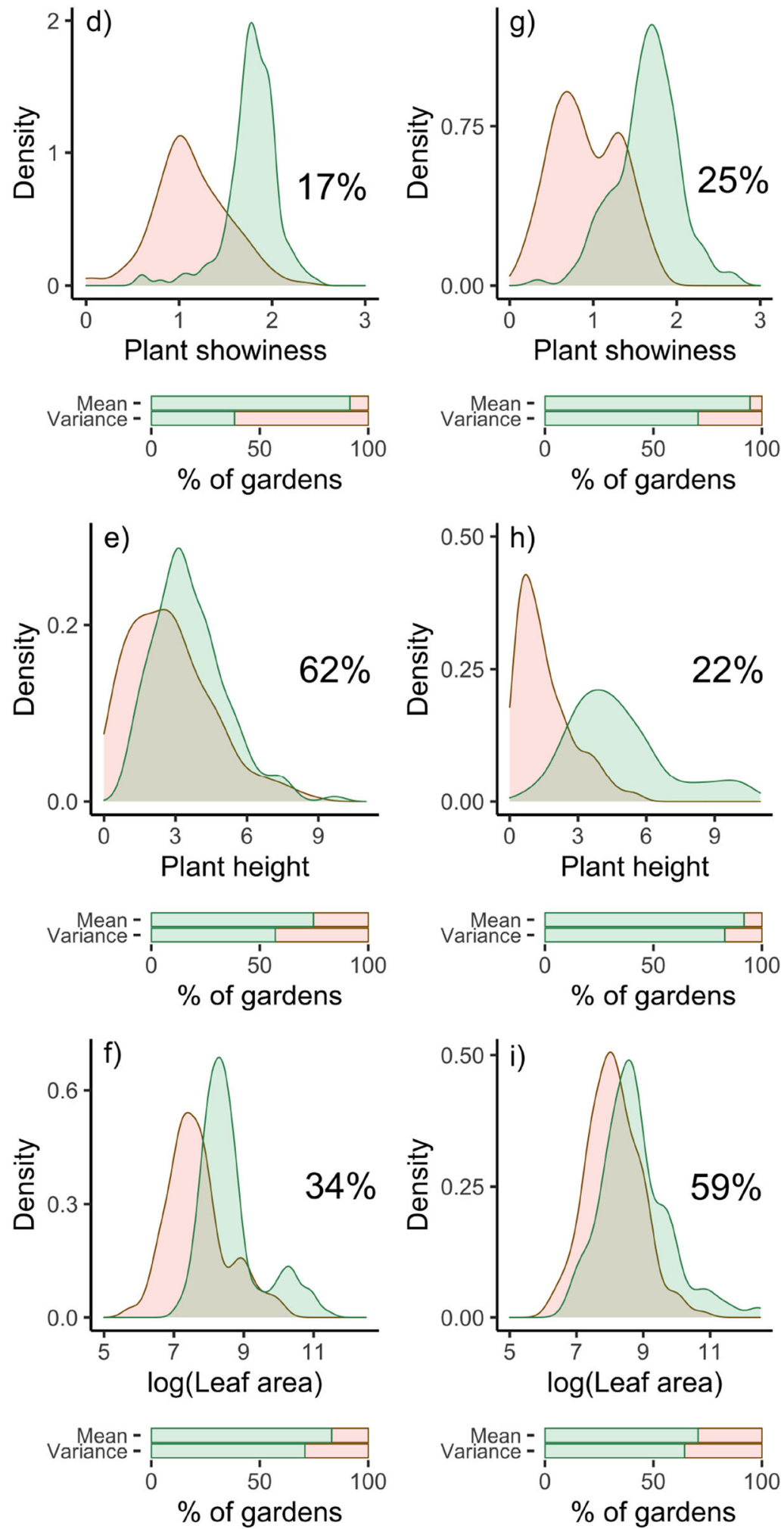
4Figure 3. Density curves for community means (CM) of the three plant traits (that is, plant showiness, plant height, and leaf area) separately for cultivated exotics and natives in domestic gardens in Minnesota (a-c), Alt Empordà $(d-f)$, and central South Africa (g-i). The proportion $(\%)$ of overlap between the two groups of co-occurring species is provided next to the density curves. Stacked bar plots in the bottom panels represent the proportion of gardens in each region where the mean or the variance of each particular trait was higher among cultivated exotics than among natives (spontaneous + cultivated).

natives that are showier than cultivated exotics. However, such combinations of native species might not be realizable if other traits such as growth form, plant shape, and size, or time of flowering, which we did not include in our study, are more important in explaining planting decisions. In fact, the creation of 'beauty' in domestic gardens is achieved by combining plants with different desired traits, including showiness or attractiveness, but also care, neatness or naturalness (Clayton 2007; Marco and others 2010; Kendal and others 2012a; Goodness and others 2016). These traits are usually chosen from among the pool of available ornamental species in nurseries or garden centers (Padullés Cubino and others 2015; Cavender-Bares and others 2020), which is composed primarily of exotic species. Thus, given the importance of nurseries in filling homeowners' demand for garden cultivars, and both availability and prices driving cultivated plant's likelihood of becoming invasive (Dehnen-Schmutz and others 2007), there is the need for more knowledge of the factors that drive decision-making in the regional to global horticultural industry.

Consistent with our initial hypothesis, the effect of cultivated exotics on the mean and variance of plant height, and mean leaf area, was mediated by water stress (that is, aridity), with greater positive effects of cultivated exotics in more arid (hotter and drier) regions. We expected this because, although native vegetation in more arid regions is usually dominated by short shrubs, dry grasses, and other small-leaved and drought-tolerant species (Shmida 1985), human management in the form of irrigation can compensate for the lack of precipitation in gardens (Kendal and others 2012b; Padullés Cubino and others 2019), and help create new ecological niches that can potentially be filled by taller and broader-leaved cultivated exotics. Accordingly, the cold and humid continental climate in Min- nesota resulted in co-occurring natives being taller, with greater variance in plant height, and broader leaves than co-occurring cultivated exotics, whereas the opposite was true for the semi-arid central area of South Africa. Moreover, gardens in Alt Empordà, with its intermediate arid conditions, showed a transition state between these two regions. Thus, cultivated exotic and native plants seemed to be combined in domestic gardens to encompass a range of growth forms and sizes that promoted greater structural diversity, a pattern shown to be preferred by homeowners in a number of studies (Ulrich 1986; Kaplan and Kaplan 1989; Williams 2002). Further exploration of the differences between functional diversity of cultivated exotics and natives among social and cultural groups would require fine-scale data, such as household income, age, and cultural background, collected throughout different regions.

The increase in flower, fruit, and leaf showiness in gardens as a consequence of the cultivation of exotic species might have implications beyond the provision of cultural ecosystem services such as aesthetics or recreation. For instance, some crucial ecosystem functions, such as pollination or the provision of food and habitat to natural wildlife, can be both positively and negatively affected (Pyšek and others 2012; Johnson and others 2017). On the one hand, (showy) cultivated exotics can positively increase pollinator services by sustaining large pollinator populations (Haaland and others 2011), increase native plant genetic diversity via hybridization (Stockwell and others 2003), or help provide biotic resistance to invasion (Levine and others 2004). On the other hand, cultivated exotics can also induce a reduction of pollinator populations because of a loss of specialist pollinators or increased heterospecific pollen deposition (Ashman and Arceo-Gómez 2013), decrease native plant genetic diversity via gene flow (Selbo and Snow 2005) or facilitate the transmission of novel pests and pathogens (McArt and others 2014). Likewise, increased plant height and leaf area in domestic gardens can also induce changes in a number of ecosystem services, besides visual attractiveness. For instance, although a wider range of plant heights and leaf sizes can increase $\mathrm{CO}_{2}$ sequestration, improve air quality, facilitate more efficient light interception, and help regulate water balance, it can also increase water requirements, produce larger amounts of allergens, or generate unwanted litter (Westoby and others 2002; Cameron and others 2012). Therefore, trade-offs between ecosystem services and disservices provided by cultivated exotics can create conflicts over whether 
to manage for the former or the latter, and the integration of the two requires an assessment of the demands of human beneficiaries (Milanović and others 2020).

Although we calculated the functional diversity of domestic gardens for individual plant traits, ecosystem function and associated services might not be the expression of just one trait but the aggregate of multiple traits within a category. These complex trait-service associations can be useful for identifying the different trait combinations that can support a variety of ecosystem services in the urban landscape. For example, research has shown that general aesthetic appreciation of plants is associated with large, spreading canopies, showy flowers, and broad-shaped foliage (for example, Williams 2002; Kendal and others 2012a; Goodness and others 2016). Accordingly, our study indicates that the combination of these traits captures meaningful aspects of aesthetic ecosystem services, as gardens with a higher proportion of cultivated exotics hosted showier and taller vegetation with larger leaves, resulting in overall higher aesthetic appeal. However, a consistent positive effect of cultivated exotics on the diversity of the three studied traits was only detected in more arid regions, highlighting that linkages between multiple traits and services of cultivated species are not necessarily universal and that these linkages may differ widely or have specific nuances across cultures and geographic locations. In addition, homeowners select for plant traits associated with a wide range of ecosystem services types, from cultural (including aesthetics and symbolic meanings), to provisioning (utility and food) and regulating and supporting (environmental suitability, native vegetation, and resource use) (Larson and others 2016). Therefore, considering the interaction among multifunctional landscape goals, homeowners' management activities (for example, watering and selective plant removal), and climate, is essential for promoting diverse garden plant communities that maximize targeted services while also supporting low-maintenance native species that are adapted to the local environment.

Our study relied on mean species trait values collated from global databases for two of the three traits studied. We thus acknowledge that the traitbased results from our study do not specifically capture trait variation in our urban populations, which are often exposed to unique selection pressures that can uniquely influence the expression of different phenotypes (for example, Cheptou and others 2008). Although these differences can strongly influence trait patterns within sites at the local scale, at very broad scales (for example, transcontinental), intraspecific trait variation is minimized and likely does not have a strong effect on community-level trait values (that is, interspecific trait variation) (Albert and others 2011). Similarly, the taxonomic classification of garden plants at the species level excludes the possibility of accounting for trait variation among cultivars and subspecies, which can also respond to human preferences. We also note that trait availability was relatively low for our study species, especially among cultivated taxa and for leaf area $58 \%$ of total species). Although we believe these limitations were largely mitigated by using an extensive dataset with 1863 species, and trait imputation techniques (Appendix S3), the collection and publication of additional trait data, particularly from species in urban habitats, and the use of standardized measures of species abundances, would allow further corroboration of our conclusions.

Overall, our study indicates that cultivated exotics play an important role in increasing the visibility and aesthetic value of domestic gardens, with concomitant potential impacts on associated ecosystem services and disservices. However, this role varied across regions of different aridity, indicating that the effects of cultivated exotics on urban ecosystem function is likely to intensify with ongoing urban expansion, and climate change, as many regions are projected to become hotter and drier by the end of the 21 st century (IPCC 2014). If cities become more arid, it is possible that certain services may be augmented, reduced, or eliminated. Likewise, new contributions may be added to the list of urban-based ecosystem services, as the structure and trait composition of urban vegetation changes. These changes can be associated with gains and losses of particular sets of cultivated exotics with specific traits selected for by humans. In addition, climate change is likely to be a key driver in the local extirpation of many native species, thereby emphasizing the importance of developing sustainable urbanization strategies that reconcile the cost-benefits of exotics species, as they relate to ecosystem services and the conservation of native biodiversity. In more arid landscapes, strategies that enhance water provision in urban areas can also promote biodiversity and the benefits associated with it, as well as enhance the resilience of urban areas to the effects of climate change. Finally, as the imports of ornamental liveplants continue to increase globally (van Kleunen and others 2018), a better understanding of the different garden fashions and the factors that drive 
decision-making in the horticultural industry can help us predict the future effects of cultivated exotic species on ecosystem function and the provisioning of ecosystem services.

\section{ACKNOWLEDGEMENTS}

This paper resulted from a series of workshops held at German Centre for Integrative Biodiversity Research (iDiv) Halle-Jena-Leipzig, Germany, which was funded by sDiv (Working group: sUrBioCityDeciphering Drivers of Urban Biodiversity across Multiple Scales). We thank botanists involved in field sampling and homeowners for giving permission to sample in their gardens.

\section{DATA AVAILABILITY STATEMENT}

Datasets are publicly available for domestic gardens in Spain (https://doi.org/10.6084/m9.figshare.770 4563.v1), the USA (https://doi.org/10.6073/pasta/a 9765d8ald4ea8840490d454dba3d6e7; https://doi. org/10.13020/89ae-2877), and South Africa (http s://doi.org/10.6084/m9.figshare.12890645.v1).

\section{OPEN ACCESS}

This article is licensed under a Creative Commons Attribution 4.0 International License, which permits use, sharing, adaptation, distribution and reproduction in any medium or format, as long as you give appropriate credit to the original author(s) and the source, provide a link to the Creative Commons licence, and indicate if changes were made. The images or other third party material in this article are included in the article's Creative Commons licence, unless indicated otherwise in a credit line to the material. If material is not included in the article's Creative Commons licence and your intended use is not permitted by statutory regulation or exceeds the permitted use, you will need to obtain permission directly from the copyright holder. To view a copy of this licence, visit $h$ ttp://creativecommons.org/licenses/by/4.0/.

\section{REFERENCES}

Acar C, Acar H, Eroğlu E. 2007. Evaluation of ornamental plant resources to urban biodiversity and cultural changing: A case study of residential landscapes in Trabzon city (Turkey). Building and Environment 42:218-29.

Albert CH, Grassein F, Schurr FM, Vieilledent G, Violle C. 2011. When and how should intraspecific variability be considered in trait-based plant ecology? Perspectives in Plant Ecology, Evolution and Systematics 13:217-25.

Anderson DR. 2008. Model based inference in the life sciences: A prime on evidence. New York: Springer.
Aronson MF, Nilon CH, Lepczyk CA, Parker TS, Warren PS, Cilliers SS, Goddard MA, Hahs AK, Herzog C, Katti M. 2016. Hierarchical filters determine community assembly of urban species pools. Ecology 97:2952-63.

Aronson MFJ, La Sorte FA, Nilon CH, Katti M, Goddard MA, Lepczyk CA, Warren PS, Williams NSG, Cilliers S, Clarkson B, Dobbs C, Dolan R, Hedblom M, Klotz S, Kooijmans JL, Kuhn I, MacGregor-Fors I, McDonnell M, Mortberg U, Pysek P, Siebert S, Sushinsky J, Werner P, Winter M. 2014. A global analysis of the impacts of urbanization on bird and plant diversity reveals key anthropogenic drivers. Proceedings of the Royal Society B: Biological Sciences 281:20133330.

Ashman T-L, Arceo-Gómez G. 2013. Toward a predictive understanding of the fitness costs of heterospecific pollen receipt and its importance in co-flowering communities. American Journal of Botany 100:1061-70.

Avolio M, Pataki DE, Jenerette GD, Pincetl S, Clarke LW, Cavender-Bares J, Gillespie TW, Hobbie SE, Larson KL, McCarthy HR, Trammell TLE. 2019. Urban plant diversity in Los Angeles, California: Species and functional type turnover in cultivated landscapes. Plants People Planet:ppp3.10067.

Avolio ML, Pataki DE, Gillespie TW, Jenerette GD, McCarthy HR, Pincetl S, Weller Clarke L. 2015. Tree diversity in southern California's urban forest: the interacting roles of social and environmental variables. Frontiers in Ecology and Evolution 3. http://journal.frontiersin.org/Article/10.3389/fe vo.2015.00073/abstract. Last accessed 21/11/2017.

Avolio ML, Pataki DE, Trammell TLE, Endter-Wada J. 2018. Biodiverse cities: The nursery industry, homeowners, and neighborhood differences drive urban tree composition. Ecological Monographs 88:259-76.

Bartón K. 2019. MuMIn: Multi-Model Inference. R package version 1.43.6. https://CRAN.R-project.org/package=MuMIn

de Bello F, Lavorel S, Díaz S, Harrington R, Cornelissen JHC, Bardgett RD, Berg MP, Cipriotti P, Feld CK, Hering D, Martins da Silva P, Potts SG, Sandin L, Sousa JP, Storkey J, Wardle DA, Harrison PA. 2010. Towards an assessment of multiple ecosystem processes and services via functional traits. Biodivers Conserv 19:2873-93.

Bigirimana J, Bogaert J, De Cannière C, Bigendako M-J, Parmentier I. 2012. Domestic garden plant diversity in Bujumbura, Burundi: Role of the socio-economical status of the neighborhood and alien species invasion risk. Landscape and Urban Planning 107:118-26.

Bolós O, Vigo J, Masallés RM, Ninot JM. 2005. Flora manual dels Països Catalans. 3rd edn. Barcelona: Editorial Pòrtic.

Cade BS. 2015. Model averaging and muddled multimodel inferences. Ecology 96:2370-82.

Cameron RWF, Blanuša T, Taylor JE, Salisbury A, Halstead AJ, Henricot B, Thompson K. 2012. The domestic garden - Its contribution to urban green infrastructure. Urban Forestry $\delta$ Urban Greening 11:129-37.

Cavender-Bares J, Padullés Cubino J, Pearse WD, Hobbie SE, Lange AJ, Knapp S, Nelson KC. 2019. Horticultural availability and homeowner preferences drive plant diversity and composition in urban yards. https://doi.org/10.13020/89ae-2 877.

Cavender-Bares J, Padullés Cubino J, Pearse WD, Hobbie SE, Lange AJ, Knapp S, Nelson KC. 2020. Horticultural availability and homeowner preferences drive plant diversity and composition in urban yards. Ecol Appl:eap.2082.

Cayuela L, Stein A, Oksanen J. 2017. Taxonstand: Taxonomic Standardization of Plant Species Names. R package version 20. 
https://CRAN.R-project.org/package=Taxonstand. Last accessed 05/09/2017.

Cheptou P-O, Carrue O, Rouifed S, Cantarel A. 2008. Rapid evolution of seed dispersal in an urban environment in the weed Crepis sancta. Proceedings of the National Academy of Sciences 105:3796-9.

Clayton S. 2007. Domesticated nature: Motivations for gardening and perceptions of environmental impact. Journal of Environmental Psychology 27:215-24.

Cook-Patton SC, Agrawal AA. 2014. Exotic plants contribute positively to biodiversity functions but reduce native seed production and arthropod richness. Ecology 95:1642-50.

Cornelissen JHC, Lavorel S, Garnier E, Díaz S, Buchmann N, Gurvich DE, Reich PB, ter Steege H, Morgan HD, van der Heijden MGA, Pausas JG, Poorter H. 2003. A handbook of protocols for standardised and easy measurement of plant functional traits worldwide. Aust J Bot 51:335.

Dehnen-Schmutz K, Touza J, Perrings C, Williamson M. 2007. The Horticultural Trade and Ornamental Plant Invasions in Britain. Conservation Biology 21:224-31.

Díaz S, Kattge J, Cornelissen JHC, Wright IJ, Lavorel S, Dray S, Reu B, Kleyer M, Wirth C, Colin Prentice I, Garnier E, Bönisch G, Westoby M, Poorter H, Reich PB, Moles AT, Dickie J, Gillison AN, Zanne AE, Chave J, Joseph Wright S, Sheremet'ev SN, Jactel H, Baraloto C, Cerabolini B, Pierce S, Shipley B, Kirkup D, Casanoves F, Joswig JS, Günther A, Falczuk V, Rüger N, Mahecha MD, Gorné LD. 2016. The global spectrum of plant form and function. Nature 529:167-71.

Fick SE, Hijmans RJ. 2017. WorldClim 2: new 1-km spatial resolution climate surfaces for global land areas: New climate surfaces for global land areas. Int J Climatol 37:4302-15.

Germishuizen G, Meyer NL, Steenkamp Y, Keith M. 2006. A checklist of South African plants. Southern African Botanical Diversity Network Report No. 41. Pretoria, South Africa: SABONET.

Glen HF. 2002. Cultivated plants of southern Africa. Johannesburg: Jacana.

Goodness J. 2018. Urban landscaping choices and people's selection of plant traits in Cape Town, South Africa. Environmental Science \& Policy 85:182-92.

Goodness J, Andersson E, Anderson PML, Elmqvist T. 2016. Exploring the links between functional traits and cultural ecosystem services to enhance urban ecosystem management. Ecological Indicators 70:597-605.

Goolsby EW, Bruggeman J, Ané C. 2017. Rphylopars : fast multivariate phylogenetic comparative methods for missing data and within-species variation. Fitzjohn R, editor. Methods in Ecology and Evolution 8:22-7.

Groffman PM, Grove JM, Polsky C, Bettez ND, Morse JL, Cavender-Bares J, Hall SJ, Heffernan JB, Hobbie SE, Larson KL, Neill C, Nelson K, Ogden L, O'Neil-Dunne J, Pataki D, Chowdhury RR, Locke DH. 2016. Satisfaction, water and fertilizer use in the American residential macrosystem. Environmental Research Letters 1 1:034004.

Haaland C, Naisbit RE, Bersier L-F. 2011. Sown wildflower strips for insect conservation: A review: Wildflower strips for insect conservation. Insect Conservation and Diversity 4:60-80.

van Heezik Y, Freeman C, Porter S, Dickinson KJM. 2013. Garden size, householder knowledge, and socio-economic status influence plant and bird diversity at the scale of individual gardens. Ecosystems 16:1442-54.
Hijmans R. 2019. raster: Geographic Data Analysis and Modeling. https://CRAN.R-project.org/package=raster.

IPCC. 2014. Climate Change 2014: Synthesis Report. Contribution of Working Groups I, II and III to the Fifth Assessment Report of the Intergovernmental Panel on Climate Change [Core Writing Team, R.K. Pachauri and L.A. Meyer (eds.)]. IPCC, Geneva, Switzerland.

Johnson AL, Fetters AM, Ashman T-L. 2017. Considering the unintentional consequences of pollinator gardens for urban native plants: Is the road to extinction paved with good intentions? New Phytol 215:1298-305.

Kaplan R, Kaplan S. 1989. The Experience of Nature: A Psychological Perspective. Cambridge: Cambridge University Press.

Kaufman AJ, Lohr VI. 2004. Does plant color affect emotional and physiological responses to landscapes? Acta Hortic:22933.

Kendal D, Williams KJH, Williams NSG. 2012a. Plant traits link people's plant preferences to the composition of their gardens. Landscape and Urban Planning 105:34-42.

Kendal D, Williams NSG, Williams KJH. 2012b. A cultivated environment: Exploring the global distribution of plants in gardens, parks and streetscapes. Urban Ecosystems 15:637-52.

van Kleunen M, Essl F, Pergl J, Brundu G, Carboni M, Dullinger S, Early R, González-Moreno P, Groom QJ, Hulme PE, Kueffer C, Kühn I, Máguas C, Maurel N, Novoa A, Parepa M, Pyšek P, Seebens H, Tanner R, Touza J, Verbrugge L, Weber E, Dawson W, Kreft H, Weigelt P, Winter M, Klonner G, Talluto MV, Dehnen-Schmutz K. 2018. The changing role of ornamental horticulture in alien plant invasions: Horticulture and plant invasions. Biol Rev 93:1421-37.

Larson KL, Nelson KC, Samples SR, Hall SJ, Bettez N, CavenderBares J, Groffman PM, Grove M, Heffernan JB, Hobbie SE, Learned J, Morse JL, Neill C, Ogden LA, O'Neil-Dunne J, Pataki DE, Polsky C, Chowdhury RR, Steele M, Trammell TLE. 2016. Ecosystem services in managing residential landscapes: Priorities, value dimensions, and cross-regional patterns. Urban Ecosystems 19:95-113.

Levine JM, Adler PB, Yelenik SG. 2004. A meta-analysis of biotic resistance to exotic plant invasions: Biotic resistance to plant invasion. Ecology Letters 7:975-89.

Lindemann-Matthies P, Bose E. 2007. Species richness, structural diversity and species composition in meadows created by visitors of a botanical garden in Switzerland. Landscape and Urban Planning 79:298-307.

Loram A, Thompson K, Warren PH, Gaston KJ. 2008. Urban domestic gardens (XII): The richness and composition of the flora in five UK cities. Journal of Vegetation Science 19:32130.

Lubbe CS, Siebert SJ, Cilliers SS. 2010. Political legacy of South Africa affects the plant diversity patterns of urban domestic gardens along a socio-economic gradient. Scientific Research and Essays 5:2900-10.

Marco A, Barthelemy C, Dutoit T, Bertaudière-Montes V. 2010. Bridging Human and Natural Sciences for a Better Understanding of Urban Floral Patterns: the Role of Planting Practices in Mediterranean Gardens. Ecology and Society 15. h ttp://www.ecologyandsociety.org/vol15/iss2/art2/. Last accessed 29/01/2019.

Mazerolle MJ. 2019. AICcmodavg: Model selection and multimodel inference based on (Q)AIC(c). R package version 2.2-2 https://cran.r-project.org/package=AICcmodavg. 
McArt SH, Koch H, Irwin RE, Adler LS. 2014. Arranging the bouquet of disease: Floral traits and the transmission of plant and animal pathogens. Gurevitch J, editor. Ecol Lett 17:62436.

Milanović M, Knapp S, Pyšek P, Kühn I. 2020. Linking traits of invasive plants with ecosystem services and disservices. Ecosystem Services 42:101072.

Millennium Ecosystem Assessment, Ed. 2005. Ecosystems and human well-being: synthesis. Washington, DC: Island Press.

Nobis MP, Jaeger JAG, Zimmermann NE. 2009. Neophyte species richness at the landscape scale under urban sprawl and climate warming. Diversity and Distributions 15:928-39.

Padullés Cubino J. 2019. Plant presence/absence in suburban domestic gardens (Alt Empordà, Catalonia). https://doi.org/ 10.6084/m9.figshare.7704563.v1.

Padullés Cubino J, Avolio ML, Wheeler MM, Larson KL, Hobbie SE, Cavender-Bares J, Hall SJ, Nelson KC, Trammell TLE, Neill C, Pataki DE, Grove JM, Groffman PM. 2020. Linking yard plant diversity to homeowners' landscaping priorities across the U.S. Landscape and Urban Planning 196:103730.

Padullés Cubino J, Cavender-Bares J, Hobbie SE, Pataki DE, Avolio ML, Darling LE, Larson KL, Hall SJ, Groffman PM, Trammell TLE, Steele MK, Grove JM, Neill C. 2019. Drivers of plant species richness and phylogenetic composition in urban yards at the continental scale. Landscape Ecology 34:63-77.

Padullés Cubino J, Narango D. 2019. American Residential Macrosystems - Presence/absence and cultivation status of plant species within residential yards in seven major metropolitan areas, 2012-2013. https://doi.org/10.6073/past a/a9765d8ald4ea8840490d454dba3d6e7.

Padullés Cubino J, Vila Subirós J, Barriocanal Lozano C. 2015. Propagule pressure from invasive plant species in gardens in low-density suburban areas of the Costa Brava (Spain). Urban Forestry \& Urban Greening 14:941-51.

Paradis E, Schliep K. 2019. ape 5.0: an environment for modern phylogenetics and evolutionary analyses in R. Schwartz R, editor. Bioinformatics 35:526-8.

Pataki DE, McCarthy HR, Gillespie T, Jenerette GD, Pincetl S. 2013. A trait-based ecology of the Los Angeles urban forest. Ecosphere 4:72.

Pavoine S, Bonsall MB, Dupaix A, Jacob U, Ricotta C. 2017. From phylogenetic to functional originality: Guide through indices and new developments. Ecological Indicators 82:196205.

Pearse WD, Cadotte MW, Cavender-Bares J, Ives AR, Tucker CM, Walker SC, Helmus MR. 2015. Pez: Phylogenetics for the environmental sciences. Bioinformatics 31:2888-90.

Pearse WD, Cavender-Bares J, Hobbie SE, Avolio ML, Bettez N, Roy Chowdhury R, Darling LE, Groffman PM, Grove JM, Hall SJ, Heffernan JB, Learned J, Neill C, Nelson KC, Pataki DE, Ruddell BL, Steele MK, Trammell TLE. 2018. Homogenization of plant diversity, composition, and structure in North American urban yards. Ecosphere 9:e02105.

Pérez-Harguindeguy N, Díaz S, Garnier E, Lavorel S, Poorter H, Jaureguiberry P, Bret-Harte MS, Cornwell WK, Craine JM, Gurvich DE, Urcelay C, Veneklaas EJ, Reich PB, Poorter L, Wright IJ, Ray P, Enrico L, Pausas JG, de Vos AC, Buchmann N, Funes G, Quétier F, Hodgson JG, Thompson K, Morgan HD, ter Steege H, Sack L, Blonder B, Poschlod P, Vaieretti MV, Conti G, Staver AC, Aquino S, Cornelissen JHC. 2013. New handbook for standardised measurement of plant functional traits worldwide. Australian Journal of Botany 61:167.
Pinheiro J, Bates D, DebRoy S, Sarkar D, R Core Team. 2018. nlme: Linear and Nonlinear Mixed Effects Models. https:// CRAN.R-project.org $/$ package $=$ nlme .

Pyšek P, Bacher S, Chytrý M, Jarošík V, Wild J, Celesti-Grapow L, Gassó N, Kenis M, Lambdon PW, Nentwig W, Pergl J, Roques A, Sádlo J, Solarz W, Vilà M, Hulme PE. 2010. Contrasting patterns in the invasions of European terrestrial and freshwater habitats by alien plants, insects and vertebrates: Invasion of European habitats by alien plants and animals. Global Ecology and Biogeography 19:317-31.

Pyšek P, Jarošík V, Hulme PE, Pergl J, Hejda M, Schaffner U, Vilà M. 2012. A global assessment of invasive plant impacts on resident species, communities and ecosystems: The interaction of impact measures, invading species' traits and environment. Glob Change Biol 18:1725-37.

Qian H, Jin Y. 2016. An updated megaphylogeny of plants, a tool for generating plant phylogenies and an analysis of phylogenetic community structure. Journal of Plant Ecology 9:233-9.

R Core Team. 2019. R: A language and environment for statistical computing. Vienna, Austria: R Foundation for Statistical Computing https://www.R-project.org/.

Selbo SM, Snow AA. 2005. Flowering phenology and genetic similarity among local and recently introduced populations of andropogon gerardii in ohio. Restor Ecology 13:441-7.

Shmida A. 1985. Biogeography of the desert flora. Hot Deserts and Arid Shrublands: Ecosystems of the World, Vol. 12. New York: Elsevier Sci. p 23-77.

Siebert S, Cilliers S, Davoren E, Lubbe R, Komape D, Knoetze L, Khanyi H, Molebatsi L, Padullés Cubino J. 2020. Plant presence/absence in suburban domestic gardens in South Africa. figshare. Dataset. https://doi.org/10.6084/m9.figshare.12890 645.v1.

Southon GE, Jorgensen A, Dunnett N, Hoyle H, Evans KL. 2017. Biodiverse perennial meadows have aesthetic value and increase residents' perceptions of site quality in urban greenspace. Landscape and Urban Planning 158:105-18.

Stockwell CA, Hendry AP, Kinnison MT. 2003. Contemporary evolution meets conservation biology. Trends in Ecology $\delta$ Evolution 18:94-101.

Swenson NG. 2014. Phylogenetic imputation of plant functional trait databases. Ecography 37:105-10.

Todorova A, Asakawa S, Aikoh T. 2004. Preferences for and attitudes towards street flowers and trees in Sapporo, Japan. Landscape and Urban Planning 69:403-16.

Trabucco A, Zomer RJ. 2019. Global Aridity Index and Potential Evapotranspiration (ET0) Climate Database v2. https://doi.or g/10.6084/m9.figshare.7504448.v3.

Tratalos J, Fuller RA, Warren PH, Davies RG, Gaston KJ. 2007. Urban form, biodiversity potential and ecosystem services. Landscape and Urban Planning 83:308-17.

Ulrich RS. 1986. Human responses to vegetation and landscapes. Landscape and Urban Planning 13:29-44.

Desa UN. 2018. World urbanization prospects: The 2018 revision. New York: United Nations.

Walther G-R, Roques A, Hulme PE, Sykes MT, Pyšek P, Kühn I, Zobel M, Bacher S, Botta-Dukát Z, Bugmann H et al. 2009. Alien species in a warmer world: Risks and opportunities. Trends in Ecology \& Evolution 24:686-93.

Westoby M, Falster DS, Moles AT, Vesk PA, Wright IJ. 2002. Plant ecological strategies: Some leading dimensions of variation between species. Annual Review of Ecology and Systematics 33:125-59. 
Williams K. 2002. Exploring resident preferences for street trees in Melbourne, Australia. Journal of Arboricltur 28:161-70.

Zanne AE, Tank DC, Cornwell WK, Eastman JM, Smith SA, FitzJohn RG, McGlinn DJ, O'Meara BC, Moles AT, Reich PB, Royer DL, Soltis DE, Stevens PF, Westoby M, Wright IJ, Aarssen L, Bertin RI, Calaminus A, Govaerts R, Hemmings F,
Leishman MR, Oleksyn J, Soltis PS, Swenson NG, Warman L, Beaulieu JM. 2014. Three keys to the radiation of angiosperms into freezing environments. Nature 506:89-92.

Zuur AF, Ieno EN, Smith GM. 2007. Analysing ecological data. New York: Springer. 